\title{
PENGARUH PENERAPAN MODEL DISCOVERY LEARNING MELALUI MEDIA NYATA TERHADAP KEMAMPUAN KONSEPTUAL DAN BERPIKIR KRITIS SISWA PADA PEMBELAJARAN IPA KELAS IV SD NEGERI 45 KOTA BENGKULU
}

\author{
Desti Susianita $^{1)}$, Irwan Koto, M.Ed., Ph.D. ${ }^{2)}$ \\ Fakultas Keguruan dan Ilmu Pendidikan, Universitas Bengkulu \\ destisusianita@gmail.com.
}

\begin{abstract}
Penelitian ini dilatarbelakangi oleh kemampuan pemahaman konsep dan kemampuan berpikir kritis siswa masih rendah serta cara mengajar guru dengan metode ceramah dan jarang menggunakan media pembelajaran. Tujuan penelitian ini adalah untuk menganalis pengaruh penerapan model discovery learning terhadap pemahaman konsep dan kemampuan berpikir kritis siswa dalam pembelajaran ipa siswa kelas iv sdn 45 kota bengkulu melalui media nyata. Jenis penelitian ini adalah penelitian eksperimen. Teknik pengumpulan data melalui observasi, lembar validasi dan instrumen soal. Subjek penelitian adalah siswa kelas IV SD Negeri 45 Bengkulu yang berjumlah 30 siswa pada kelas eksperimen dan 28 siswa pada kelas kontrol. Intrumen soal divalidasi oleh 3 orang ahli dan dianalisis menggunakan aiken,s $\mathrm{V}$ diperoleh 0,67 dengan kategori validitas tinggi. Hasil analisis uji t pada pemahaman konsep diperoleh 1,90 sedangkan hasil analisis uji t pada kemampuan berpikir kritis diperoleh 1,86. $\mathrm{T}_{\text {tabel }}$ dengan $\mathrm{dk}(\mathrm{N}-2=56)$ dan $\alpha=5 \%$ adalah 1,607. Dengan demikian $t_{\text {hiutng }}>\mathrm{t}_{\text {tabel }}$ maka disimpulkan bahwa terdapat pengaruh yang signifikan. Hasil penelitian ini menunjukkan bahwa terdapat pengaruh penerapan model discovery learning melalui media nyata terhadap pemahaman konsep dan berpikir kritis siswa kelas IV SD Negeri 45 Kota Bengkulu.
\end{abstract}

Kata Kunci : DL, Media Nyata, Pemahaman Konsep, berpikir krit

\begin{abstract}
This research is motivated by the ability to understand concepts and students' critical thinking skills are still low and how to teach teachers with the lecture method and rarely use learning media. The purpose of this study was to analyze the influence of the application of the discovery learning model to the understanding of concepts and critical thinking skills of students in IPA learning in grade IV students in 45 cities in Bengkulu through real media. This type of research is experimental research. The technique of collecting data through observation, validation sheets and question instruments. The research subjects were fourth grade students of 45 Bengkulu State Elementary School with 30 students in the experimental class and 28 students in the control class. Question instruments were validated by 3 experts and analyzed using aiken, $s V$ was obtained 0.67 in the category of high validity. The results of the t-test analysis on conceptual understanding were obtained 1.90 while the results of t-test analysis on critical thinking skills were obtained 1,86. $T$ table with $d k(N-2=56)$ and $\alpha=5 \%$ is 1,607. Thus thiutng > ttabel it is concluded that there is a significant effect. The results of this study indicate that there is an effect of the application of discovery learning models through real media to the understanding of concepts and critical thinking of fourth grade students of SD Negeri 45 Kota Bengkulu.
\end{abstract}

Key words : DL, Real Media, Understanding Concepts, critical thinking. 


\section{Pendahuluan}

Pembelajaran sebagai perangkat kegiatan eksternal yang dirancang untuk mendukung terjadinya beberapa proses belajar, yang sifatnya internasional. Pembelajaran tidak sama dengan mengajar karena dalam dalam pembelajaran titik beratnya ialah pada semua kejadian yang bisa berpengaruh secara langsung pada individu untuk belajar, Karwono (2017:23).

Peristiwa pembelajaran terjadi apabila subjek peserta didik secara aktif berinteraksi dengan sumber belajar yang diatur oleh guru. Dalam interaksi belajar tersebut setiap peserta didik diperlakukan sebagai manusia yang bermartabat yang minat dan potensinya perlu diwujudkan secara optimal, Karwono (2017:21). Menurut Djamarah (2010:120) dalam bahasa Arab, media adalah wasail atau wasilah yang berarti perantara atau penghantar pesan dari pengirim kepada penerima pesan. Media nyata yaitu "untuk mencapai hasil yang optimal dari proses belajar mengajar salah satu yang disarankan dalam digunakannya pula media yang bersifat langsung, bersifat nyata atau realita”. Media Nyata memegang peranan yang cukup penting dalam proses pembelajaran, media nyata dapat memperlancar dan memperjelas penyampaian materi pembelajaran, media nyata dapat menumbuhkan minat peserta didik dan dapat memberikan hubungan antara isi materi pembelajaran dan dunia nyata, agar lebih efektif peserta didik sebaiknya berinteraksi langsung dengan media nyata meyakinkan terjadinya proses informasi.

Kemampuan konseptual adalah aspek kunci dari pembelajaran. Salah satu tujuan pembelajaran yang penting adalah membuat murid memahami konsep utama dalam suatu subjek, bukan sekedar mengingat fakta yang terpisah-pisah. Dalam banyak kasus, kemampuan konseptual akan berkembang apabila guru dapat membantu murid mengeksplorasikan topik secara mendalam dan memberi mereka contoh yang tepat dan menarik dari suatu konsep. Seperti yang akan memberi mereka contoh yang tepat dan menarik dari suatu konsep.

Winarni (2012:151), berpikir adalah suatu keaktifan pribadi manusia yang mengakibatkan penemuan terarah kepada suatu tujuan, atau suatu suatu proses kognitif, suatu aktivitas mental untuk memperoleh pengetahuan. Pengetahuan akan memberikan kesempatan kepada peserta didik untuk memperoleh keterampilan-keterampilan dalam pemecahan masalah, sehingga kemampuan berpikirnya dapat dikembangkan. Betapa pentingnya pengalaman ini agar peserta didik mempunyai struktur konsep yang dapat berguna dalam menganalisis serta mengevaluasi suatu permasalahan.

Kebanyakan siswa kurang memahami pernyataan maupun pertanyaan serta kurang bisa memahami soal dalam bentuk soal cerita yang menghubungkan pada model 
pembelajaran, yang menyebabkan kurangnya kemampuan konseptual dan berpikir kritis siswa di indonesia. Adapun permasalahannya antara lain 1) siswa kurang fokus saat pelajaran berlangsung, 2) pemahaman materi siswa masih rendah, 3) siswa malu bertanya, 4) tingkat berpikir kritis siswa masih rendah, 5) penyelesaian soal kurang runtut dan jelas, 6) tidak memperhatikan saat guru memberikan materi. Hal ini terlihat bahwa kemampuan dalam berpikir kritis dilihat dari penyelesaian masalah dan keaktifan siswa dalam mengikuti pembelajaran dilihat dari aktivitas pembelajaran siswa di kelas yang masih rendah.

Berdasarkan fakta-fakta mengenai permasalahan pendidikan tersebut, diperlukan suatu model pembelajaran yang dapat meningkatkan kemampuan konseptual dan berpikir kritis siswa yang melibatkan siswa secara langsung dalam proses penemuan fakta/informasi materi yang diajarkan. Untuk mengatasi masalah tersebut, salah satu model pembelajaran yang dapat digunakan adalah model Discovery Learning. Model Discovery Learning mengembangkan cara belajar siswa aktif dengan menemukan sendiri, menyelidiki sendiri, maka hasil yang diperoleh akan setia dan tahan lama diingatan, tidak akan mudah dilupakan siswa. Dengan belajar penemuan, anak juga bisa belajar berpikir analisis dan memecahkan sendiri problem yang dihadapi, Kebiasaan ini akan ditransfer dalam kehidupan bermasyarakat (Hosnan, 2014: 281).

Berdasarkan wawancara dan observasi penenelitian di SD 45 Kota Bengkulu dinyatakan hasil belajar IPA masih rendah karena pada proses pembelajaran guru hanya menggunakan metode ceramah di depan kelas untuk menyampaikan materi dan tidak menggunakan media pembelajaran, sehingga dalam pembelajaran ini siswa menjadi diam dalam proses belajar mengajar, dalam hal tersebut mengingatkan kesempatan siswa menemukan informasi serta dalam memahami pembelajaran IPA. Dilihat dalam nilai ulangan siswa yang kecil, sehingga membuat siswa tidak mencapai kriteria ketentuan maksimum.

Oleh sebab itu untuk memperbaiki pendidikan IPA di SD diperlukan media pengajaran yang tepat dalam pendidikan IPA. Berdasarkan uraian di atas penulis mengajukan judul Pengaruh Penggunaan Penerapan Model Discovery Learning Melalui Media Nyata Terhadap Kemampuan Konseptual Dan Berpikir Kritis Siswa Pada Pembelajaran IPA Kelas IV SD Negeri 45 Kota Bengkulu. Sesuai dengan keadaan di atas maka penelitian bertujuan untuk meningkatkan Kemampuan Konseptual dan Berpikir Kritis siswa pada pembelajaran IPA dengan judul Pengaruh Penerapan Model Discovery Learning Melalui Media Nyata Terhadap Kemampuan Konseptual Dan Berpikir Kritis Siswa Pada Pembelajaran IPA Kelas IV SD Negeri 45 Kota Bengkulu.

\section{Metode Penelitian}

\section{Tempat dan Waktu Penelitian}

Penelitian ini dilaksanakan di SDNegeri

45 Kota Bengkulu.Penelitian dilakukan pada semester genap tahun ajaran 2017/2018. 


\section{Jenis, Metode dan Design Penelitian}

Jenis penelitian yang digunakan dalam penelitian ini adalah penelitian kuantitatif. Penelitian ini menggunakan metode eksperimen semu. Menurut Suryabrata, (2010:92), tujuan penelitian eksperimen semu adalah untuk memperoleh informasi yang dapat diperoleh dengan eksperimen sebenarnya dalam keadaan yang tidak memungkinkan untuk mengontrol dan/atau memanipulasikan semua variabel yang relevan. Dalam metode eksperimen terdapat dua kelompok, yaitu kelompok eksperimen dan kelompok kontrol. Penelitian ini dilakukan untuk membandingkan kemampuan konseptual dan berpikir kritis siswa dengan menggunakan model pembelajaran yang sama tetapi menggunakan media pembelajaran yang berbeda yang kemudian diuji dalam kelas yang berbeda dimana kelas pertama menjadi kelas eksperimen yang menggunakan Discovery Learning dan Media Nyata dan kelas kedua kelas kontrol dengan menggunakan Discovery Learning dan Media Gambar.

Desain penelitian yang digunakan yaitu The Matching only Pretest-Posttest Control Group Design. Menurut Fraenkel dan Norman (Winarni, 2011: 53), the matching only pretestposttest control group design mempunyai karakteristik yaitu (1) pencocokan terhadap subjek pada kelompok kontrol dan eksperimen; (2) dilakukan pretest dan posttest; (3) tidak menjamin terpenuhi ekuivalensi; (4) proses matching tidak secara random; (5) generalisasi lemah.Karakteristik di atas dibuktikan dengan dilakukan uji homogenitas terlebih dahulu untuk mengetahui apakah kedua kelas homogen atau tidak.

\section{Populasi dan Sampel}

a. Populasi

Populasi adalah wilayah generalisasi (baca: penyamarataan) yang terdiri atas: obyek/subyek yang mempunyai kualitas dan karakteristik tertentu yang ditetapkan oleh peneliti untuk dipelajari dan kemudian ditarik kesimpulannya Sugiyono, (2012:119). Populasi penelitian ini adalah siswa kelas IV SDN 45 Kota Bengkulu

Tabel 1. Data Siswa Kelas IV SDN 45 Kota Bengkulu

\begin{tabular}{|c|c|c|c|}
\hline \multirow{2}{*}{ Kelas } & \multicolumn{2}{|c|}{ Siswa } & \multirow{2}{*}{ Jumlah } \\
\cline { 2 - 4 } & Laki-laki & Perempuan & \\
\hline IVA & 8 & 18 & 30 \\
\hline IVB & 12 & 15 & 28 \\
\hline
\end{tabular}

Sumber : Kepala Sekolah SDN 45 Kota Bengkulu (2018)

b. Sampling

Total Sampling adalah teknik pengambilan sampel dimana sampel sama dengan populasi, Sugiyono (2013: 117). Alasan mengambil total sampling karena jumlah populasi yang kurang dari 100 seluruh populasi dijadikan sampel penelitian semuanya. Sampel yang di ambil dari penelitian ini adalah 58 orang.

\section{Taknik Pengumpulan Data}

Teknik pengumpulan data merupakan suatu kegiatan yang paling penting dalam penelitian. Untuk memperoleh data yang diperlukan, maka pengumpulan data dilakukan dengan : 
a. Tes hasil Belajar

Pengumpulan data merupakan suatu kegiatan mencari data di lapangan yang akan menjawab permasalahan penelitian (Lestari \&Yudhanegara, 2016: 231). Dalam penelitian ini akan dilakukan dua tes, yaitu tes pretest dan posttest.

\section{1) Pretest}

Menurut Hamzah (2014:11), pretest dilaksanakan dengan tujuan untuk mengetahui dengan materi pelajaran yang akan diajarkan telah dilakukan oleh siswa. Data pretest diperoleh melalui tes yang dilaksanakan sebelum perlakuan diberikan. Pretest ini dilakukan untuk mengetahui apakah sampel penelitian merupakan sampel berdistibusi normal dan homogen, sehingga hasil penelitian yang diharapkan benar-benar merupakan dampak dari perlakuan yang diberikan.

2) Posttest

Menurut Hamzah (2014:11), posttest dilaksanakan dengan tujuan untuk mengetahui apakah semua materi pelajaran yang penting telah dikuasai dengan baik oleh siswa. Data posttest diperoleh melalui tes yang dilaksanakan setelah perlakuan diberikan. Soal posttest yang dibuat sama dengan soal pretest.

\section{Teknik Analisis Data}

Teknik anlisis data yang digunakan dalam penelitian ini adalah analisis kuantitatif. Data yang diperoleh akan dianalisis untuk melihat apakah ada pengaruh penerapan model Discovery Learning melalui media nyata terhadap pemahaman konsep dan kemampuan berpikir kritis siswa.

\section{a. Uji Normalitas}

Uji normalitas dilakukan untuk mengetahui kenormalan distribusi data pada sampel. Pada penelitian ini, uji normalitas dilakukan dengan menggunakan rumus chikuadrat, yaitu:

$$
X^{2}=\sum \frac{\left(f_{o}-f_{e}\right)^{\overline{2}}}{f_{e}}
$$

\section{Keterangan:}

$X^{2} \quad=$ uji chi kuadrat

$f_{o} \quad=$ frekuensi yang diperoleh dari data penelitian

$f_{e} \quad=$ frekuensi yang diharapkan

Jika $X_{\text {hitung }}^{2} \leq X_{\text {tabel }}^{2}$ maka distribusi data normal sedangkan jika $X_{\text {hitung }}^{2} \geq X_{\text {tabel }}^{2}$ maka distribusi data tidak normal. Dengan taraf signifikansi $\alpha=0,05$ (Riduwan, 2013: 197)

\section{b. Uji Homogenitas}

Uji homogenitas bertujuan untuk mengetahui apakah kondisi kelas eksperimen memiliki persamaan (homogen) dengan kelas kontrol. Metode yang digunakan yaitu uji $\mathrm{F}$ dengan rumus:

$$
\mathrm{F}_{\text {hitung }}=\frac{\text { varian terbesar }}{\text { varian terkecil }}
$$

Keterangan:

$\mathrm{S}^{2}=$ varians

Dilakukan pembandingan antara $F_{\text {hitung }}$ dan $F_{\text {tabel}}$. JIka $F_{\text {hitung }} \leq \mathrm{F}_{\text {tabel }}$ maka kondisi kelas eksperimen dan kelas kontrol homoogen sedangkan jika $F_{\text {hitung }} \geq F_{\text {tabel }}$ maka kondisi tidak homogen(Riduwan, 2013: 186).

\section{c. Analisis Inferensial}

Sugiyono (2010: 209) menyatakan bahwa inferensial adalah teknik statistik yang 
digunakan untuk menganalisis data sampel dan hasilnya diberlakukan untuk populasi.Jika diketahui data yang diperoleh adalah data yang normal dan homogen, maka untuk pengujian hipotesis digunakan uji-t dua sampel independen. Rumus uji t dua sampel yaitu:

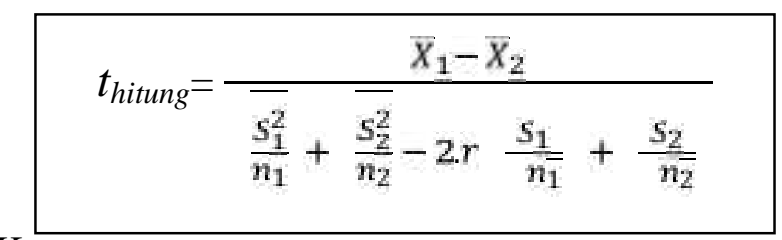

\section{Keterangan:}

$\mathrm{r}=$ nilai korelasi $\mathrm{X}_{1}$ dengan $\mathrm{X}_{2}$

$X_{1} \quad=$ rata-rata sampel ke-1

$X_{2} \quad=$ rata-rata sampel ke-2

$n_{1} \quad=$ jumlah sampel ke-1

$n_{2} \quad=$ jumlah sampel ke-2

$S_{1} \quad=$ standar deviasi sampel ke-1

$S_{2} \quad=$ standar deviasi sampel ke-2

$S_{1}^{2} \quad=$ varian kelompok ke-1

$S_{2}^{2}=$ varian kelompok ke-2

Mencari nilai $\mathrm{t}_{\text {tabel }}$ dengan ketentuan $\mathrm{db}=\mathrm{n}_{1}+$ $\mathrm{n}_{2}-2$ dengan taraf signifikansi $\alpha=0,05$. Jika $t_{\text {hitung }} \mathbb{\Im}_{\text {tabel }}$ maka $\mathrm{H}_{0}$ diterima dan $\mathrm{H}_{\mathrm{a}}$ ditolak sedangkan jika $t_{\text {hitung }} \boldsymbol{\searrow}_{\text {tabel }}$ maka $\mathrm{H}_{0}$ ditolak dan $\mathrm{H}_{\mathrm{a}}$ diterima.

\section{Hasil dan Pembahasan}

\section{Hasil Uji Normalitas Data Post-test}

Uji normalitas ini bertujuan untuk mengetahui data yang digunakan apakah berdistribusi normal atau tidak. Data yang dianalisis adalah hasil post-test kelas eksperimen dan hasil post-test kelas kontrol. Berdasarkan hasil perhitungan rekapitulasi hasil uji normalitas data tes awal (pre-test) dapat dilihat pada tabel 4.6.
Tabel 2

Hasil Uji Normalitas Post-test

Kelas eksperimen dan Kelas Kontrol Pada

Pemhaman Konsep dan Kemampuan

Berpikir Kritis Siswa

\begin{tabular}{|c|c|c|c|}
\hline & Tes & $\begin{array}{c}\text { Nilai } \\
\text { Normalitas }\end{array}$ & Keterangan \\
\hline Pemahaman & $\begin{array}{c}\text { Post-Test } \\
\text { Kelas } \\
\text { Konsperimen }\end{array}$ & 0,200 & Data Normal \\
\cline { 2 - 4 } & $\begin{array}{c}\text { Post-test } \\
\text { Kelas } \\
\text { Kontrol }\end{array}$ & 0,200 & Data Normal \\
\hline \multirow{2}{\text{Kemampuan}}{$\begin{array}{c}\text { Post-Test } \\
\text { Berpikir } \\
\text { Kritis }\end{array}$} & $\begin{array}{c}\text { Kelas } \\
\text { Eksperimen } \\
\text { Post-test } \\
\text { Kelas } \\
\text { Kontrol }\end{array}$ & 0,431 & Data Normal \\
\hline
\end{tabular}

Berdasarkan tabel 2 bahwa hasil analsis normalitas data posttest kelas ekseperimen pada pemahaman konsep yang diperoleh adalah 0,200 nilai tersebut $>0,05$ sehingga nilai data post-test kelas eksperimen pada pemahaman konsep berdistribusi normal. Sedangkan kelas kontrol pada pemahaman konsep didapat nilai $0,200>0,05$ juga berdistribusi normal karena lebih dari 0,05. Dapat disimpulkan data nilai post-test kelas eksperimen dan kelas kontrol pada pemahaman konsep berdistribusi normal. Sedangkan hasil analsis normalitas data posttest kelas ekseperimen pada kemampuan berpikir kritis yang diperoleh adalah 0,431 nilai tersebut > 0,05 sehingga nilai data post-test kelas eksperimen pada kemampuan berpikir kritis berdistribusi normal. Sedangkan kelas kontrol pada kemampuan berpikir kritis didapat nilai 
0,200 > 0,05 juga berdistribusi normal karena lebih dari 0,05. Dapat disimpulkan data nilai post-test kelas eksperimen dan kelas kontrol pada kemampuan berpikir kritis berdistribusi normal.

\section{Hasil Uji Homogenitas}

Kelas

Eksperimen dan kelas kontrol

Analisis homogenitas merupakan prasyarat uji hipotesis. Analisis yang dilakukan yaitu dengan membandingkan $\mathrm{F}_{\text {hitung }}$ dan $\mathrm{F}_{\text {tabel }}$. Hasil analisis data homogenitas dapat dilihat pada Tabel 3.

Tabel 3

Hasil Uji Homogenitas Post-Test Kelas eksperimen dan Kelas Kontrol Pada Pemahaman Konsep dan Kemampuan Berpikir Kritis

\begin{tabular}{|c|c|c|}
\hline & $\begin{array}{c}\text { Nilai } \\
\text { Homogenitas }\end{array}$ & Keterangan \\
\hline $\begin{array}{c}\text { Pemahaman } \\
\text { Konsep }\end{array}$ & 0,068 & Homogen \\
\hline $\begin{array}{c}\text { Kemampuan } \\
\text { Berpikir } \\
\text { Kritis }\end{array}$ & 0,212 & Homogen \\
\hline
\end{tabular}

Berdasarkan tabel 3 bahwa nilai homogen pada pemahaman konsep yang diperoleh adalah $0,068 \quad$ selanjutnya dibandingkan dengan nilai 0,05, karena 0,212 > 0,05 maka kelas eksperimen dan kelas kontrol pada pemahaman konsep homogen sehingga layak untuk digunakan sebagai subjek penelitian. Sedangakn nilai homogen pada kemampuan berpikir kritis kelas eksperimen dan kelas kontrol yang diperoleh adalah 0,400 selanjutnya dibandingkan dengan nilai 0,05 , karena 0,400 > 0,05 maka kelas eksperimen dan kelas control pada kemampuan berpikir kritis homogen sehingga layak untuk digunakan sebagai subjek penelitian.

\section{Pengujian Hipotesis}

Dalam penelitian ini dilakukan pengujian hipotesis menggunakan uji t-test. Peneliti menggunakan uji t-test karena data normal dan homogen, yang artinya data tersebut parametrik. Hasil pengujiaan hipotesis terhadapat kedua kelompok sampel untuk data post-test disajikan pada Tabel 4

Tabel 4

Uji t post-test Pada Pemahaman Konsep dan Kemampuan Berpikir Kritis

\begin{tabular}{|c|c|c|c|}
\hline & \multirow{2}{*}{$\begin{array}{l}\text { Deskripsi } \\
\text { Data }\end{array}$} & \multicolumn{2}{|c|}{ Data } \\
\hline & & Eksperimen & Kontrol \\
\hline \multirow{5}{*}{$\begin{array}{c}\text { Pemahaman } \\
\text { Konsep }\end{array}$} & Rata-rata & 80,53 & 77,43 \\
\hline & Varian & 12,939 & 13,650 \\
\hline & $\mathbf{N}$ & 30 & 27 \\
\hline & Nilai Uji t & \multicolumn{2}{|c|}{1,90} \\
\hline & Kesimpulan & \multicolumn{2}{|c|}{$\begin{array}{l}1,90>1,67 \text { maka } H_{0} \\
\text { ditolak, } H_{a} \text { diterima }\end{array}$} \\
\hline \multirow{5}{*}{$\begin{array}{c}\text { Kemampuan } \\
\text { Berpikir } \\
\text { Kritis }\end{array}$} & Rata-rata & 82,63 & 76,14 \\
\hline & Varian & 13,627 & 12,892 \\
\hline & $\mathbf{N}$ & 30 & 27 \\
\hline & Nilai Uji t & \multicolumn{2}{|c|}{1,86} \\
\hline & Kesimpulan & \multicolumn{2}{|c|}{$\begin{array}{l}\text { 1,86>1,67 maka } H_{0} \\
\text { ditolak, } H_{a} \text { diterima }\end{array}$} \\
\hline
\end{tabular}

Berdasarkan Tabel 4 diketahui rata-rata

hasil post-test pada kelas eksperimen $=80,53$ dan kelas kontrol $=77,43$. Berdasarkan hasil perhitungan Uji-t kelas eksperimen dan kelas kontrol pada pemahaman konsep diperoleh nilai uji t sebesar 1,90, nilai tersebut dibandingkan dengan nilai 0,05. Karena 1,90 > 1,67 maka Ha diterima, yang artinya terdapat pengaruh penerpan model discovery learning melalui media nyata terhadap kemapuan pemahaman konsep kelas IV SD Negeri 45 Kota Bengkulu. 
Sedangkan rata-rata hasil post-test pada kelas eksperimen $=82,63$ dan kelas kontrol $=$ 76,14. Berdasarkan hasil perhitungan Uji-t kelas eksperimen dan kelas kontrol pada pemahaman konsep diperoleh nilai uji t sebesar 1,86, nilai tersebut dibandingkan dengan nilai 0,05. Karena 1,86 > 1,67 maka Ha diterima, yang artinya terdapat pengaruh penerapan model discovery learning melalui media nyata terhadap kemapuan berpikir kritis kelas IV SD Negeri 45 Kota Bengkulu.

\section{Pembahasan}

Hasil dari penelitian ini menunjukkan bahwa terdapat pengaruh penerapan model discobery learning melalui media nyata terhadap kemampuan pemahaman konsep dan berpikir kritis siswa kelas IV SD Negeri 45 Kota Bengkulu. Model discovery learning merupakan model penemuan dimana siswa dibiarkan menemukan sendiri atau mengalami proses mental sendiri, guru hanya membimbing dan memberikan intruksi.

1. Pengaruh Penerapan Model Discovery Learning dalam Menggunakan Media Nyata Terhadap Pemahaman Konseptual Siswa

\section{Discovery Learning dengan} menggunakan media nyata dapat menghadirkan benda nyata, pemebelajaran seperti yang dilakukan dalam penelitian mampu atau dapat membantu menjaga perhatian dan menumbuhkan kegiatan pembelajaran yang aktif, karena siswa tentunya dapat melakukan aktivitas seperti mengamati, meraba, mendiskusikan, dan menganalisis serta mengklasifikasi. Jadi dengan belajar melalui benda nyata siswa ternyata lebih leluasa dapat melakukan kegiatan seperti mengamati proses merubah bentuk benda dan lain sebagainya.

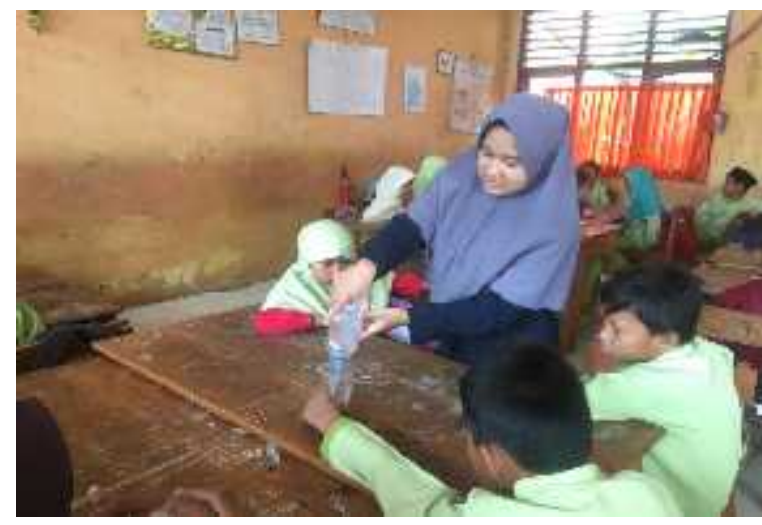

Gambar 1

Melakukan pemahaman konsep melalui media nyata

Terlihat dari gambar 1 siswa dibimbing oleh penleliti melakukan pengamtan untuk memahami sifat-sifat wujud benda cair. Siswa lebih tertarik jika permasalahan yang dimunculkan dalam proses pembentukan konsep disajikan dalam bentuk real yaitu menggunakan media nyata. Siswa lebih cepat merespon untuk mengetahui penyelesaian atau solusi dari masalah tersebut karena siswa dapat langsung mengopersikan media nyata tersebut. Karena pembelajaran yang terjadi terasa menyenangkan bagi siswa maka siswa pun antusias dalam belajar maupun dalam memecahkan soal IPA . Hal ini sesuai dengan pendapat Hamalik (Sugiyono, 2011:2) yang mengemukakan bahwa pemakaian media pembelajaran dapat membangkitkan keinginan dan minat yang baru, membangkitkan motivasi, dan rangsangan kegiatan belajar. 


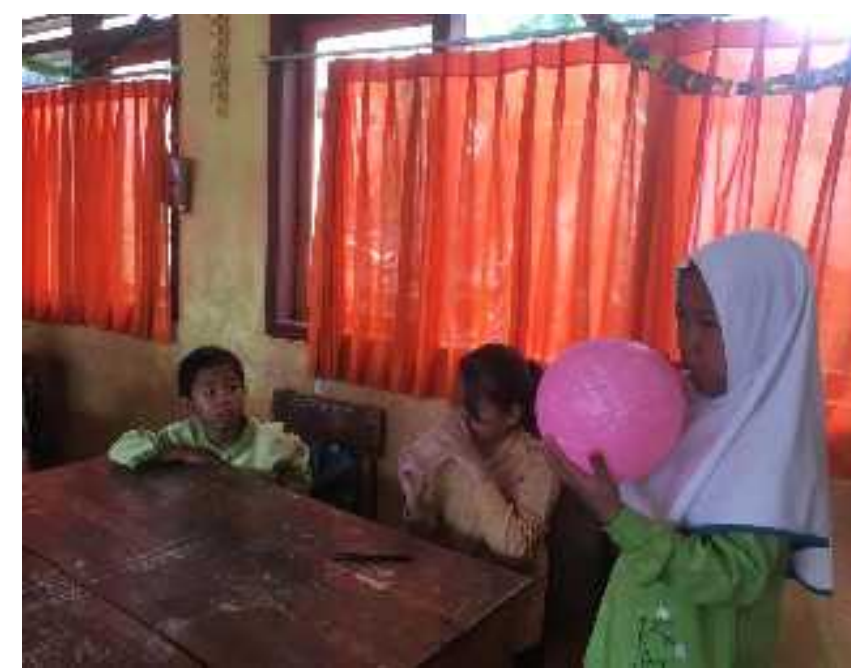

Gambar 2

Siswa mencoba melakukan penemuan konsep secara mandiri

Dari gambar 2 terlihat bahwa siswa sendiri yang mengoperasikan media nyata sehingga terbentuklah suatu konsep, maka banyak dari siswa yang memikirkan kemungkinan-kemungkinan lain dari konsep tersebut. Siswa yang memikirkan kemungkinan lain dari suatu konsep tersebut kemudian menanyakannya kepada siswa lain dan guru, sehingga terjadi interaksi aktif dalam pembelajaran. Selaras dengan teori Damon (Slavin, 2008:36) yang menyatakan bahwa interaksi di antara siswa ber- kaitan dengan tugas-tugas meningkat- kan penguasaan konsep mereka. Siswa akan mendapatkan pengetahuan yang lebih dari tanggapan siswa yang lain ataupun dari jawaban guru. Akibatnya konsep tersebut dapat dipahami oleh siswa dari berbagai kondisi sehingga siswa pada kelas eksperimen yang menggunakan media nyata mampu menyelesaikan soal- soal dengan benar

Pembelajaran menggunakan model discovery learning yang dilakukan dengan menggunakan media nyata sangat membantu siswa dalam menemukan konseptuan secara individu maupun kelompok. Sesuai dengan indikator pemahaman konsep pada penelitian ini yaitu siswa dapat menjelaskan pengertian wujud benda, menjelaskan sifat-sifat wujud benda dan memberikan contoh dari wujud benda. Hal ini searas dengan Widiyana (2014), bahwa disecovery Learning berpengaruh terhadap pemahaman konsep ipa hal ini dikarenakan discovery learning didasari oleh teori konstruktifis, siswa harus membangun sendiri pengetahuan didalam benaknya. Dan pengetahuan yang diperoleh dapat bertahan lebih lama dan dapat meningkatakan penalaran siswa dan kemampuan berpikir. Dijelaskan oleh Thoha bahwa kemampuan konseptual merupakan salah satu unsur dalam kematangan berkaitan dengan pengetahuan atau keterampilan yang dapat diperoleh dari pendidikan, pelatihan dan suatu pengalaman. Penelitian yang dilakukan adalah untuk memahami konsep pembelajaran IPA, kemampuan konsep IPA adalah cara seseorang memahami suatu konsep IPA yang telah didapat melalu serangkaian kajadian atau peristiwa yang dilihat maupun didengar yang tersimpan dalam pikiran dan yang nantinya dapat diaplikasikan dalam kehidupan sehari-hari. Kemampuan konseptual dalam penelitian ini dikhususkan pada pemahaman pada ruang lingkup untuk kelas IV pada standar kompetensi tertentu.

Hasil analisis penelitian yang dilakukan ditemukan bahwa pembelajaran menggunakan model discovery learning dalam menggunakan media nyata memiliki pengaruh 
terhadap pemahaman konseptual siswa. Penggunaan media nyata sangat membantu siswa dalam menguasai materi sehingga siswa perlahan-lahan dapat menemukan konsep dalam memahami pembelajarn IPA. Terlihat dari hasil Postest siswa dan selanjutnya dilakukan uji $\mathrm{t}$ untuk menguji hipotesis apakah terdapat pengaruh penerapan model discovery learning dalam penggunaan media nyata terhadap kemampuan konseptual pembelajaran IPA siswa kelas IV SD.

2. Pengaruh Penerapan Model Discovery Learning dalam Menggunakan Media Nyata Terhadap Berpikir Kritis Siswa

Berpikir kritis adalah berpikir yang memeriksa, menghubungkan, dan mengevaluasi semua aspek dari situasi atau masalah. Termasuk di dalamnya mengumpulkan, mengorganisir, mengingat, dan menganalisa informasi. Tujuan berpikir kritis adalah untuk mencapai pemahaman yang mendalam, pemahaman yang membuat siswa mengerti maksud dibalik ide sehingga dapat mengungkapkan makna dibalik suatu kejadian, (Novtasari, 2009:4).

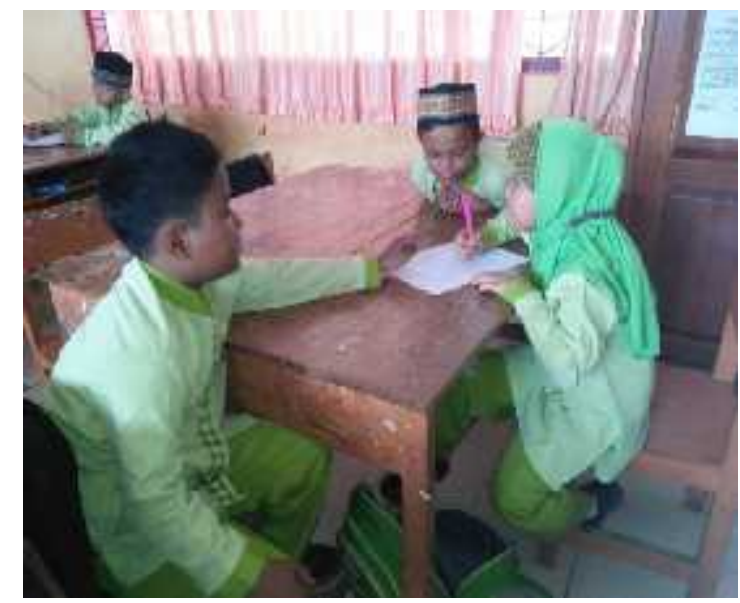

Gambar 3

Siswa melakukan pemeriksaan dan analisis
Dari hasil penelitian yang dilakukan bahwa kemampuan berpikir kritis siswa dilihat dari jawaban siswa yang berbentuk uraian. Hasil jawaban siswa mengandung pemahaman bahwa siswa tersebut mampu mengidentifikasi, menghubungkan, mengingat, mengorganisir, mengumpulkan bahkan memeriksa dan mengevaluasi. Sejalan dengan teori dari Watson dan Glaser (2010:14) yang menyatakan bahwa untuk menilai kemampuan berpikir kritis dapat dilakukan pengukuran melalui tes yang mencakup lima buah indikator, yaitu mengenal asumsi, melakukan inferensi, deduksi, interpretasi, dan mengevaluasi argumen.

Hasil penelitian diperoleh bahwa terdapat pengaruh penerapan model discovery learning dengan menggunakan media nyata terhadap berpikir kritis siswa pada materi IPA kelas IV SD 45 kota Bengkulu. Indikator kemampuan berpikir kritis yang dicapai pada penelitian ini adalah siswa dapat mengklasifikasi wuju-wjud benda, mengidentigfikasi wuju-wujud benda dan menarik kesimpulan tentang wujud benda. Hal ini selaras dengan Kristin, (2016:86) bahwa dengan belajar penemuan anak bisa berfikir lebih kritis dan mencoba memcahkan sendiri masalah yang dihadapi. Melalui penggunaan media nyata siswa mampu mengelola dan mentransformasi informasi pembelajaran secara lebih mudah karena siswa bersentuhan langsung dengan apa yang mereka pelajari. Dengan media nyata dari benda padat membuat siswa dapat menemukan sifat-sifat dari benda 
padat. Dengan media nyata benda yang berwujud cair membuat siswa dapat menemukan sifat-sifat yang benda yang berwujud cair. Dengan media nyata berwujud gas membuat siswa dapat menemukan sifat-sifat benda berwujud cair. Hal ini selaras dengan pendapat Santrock (2011:357) mengemukakan pendapatnya bahwa berpikir kritis adalah memanipulasi atau mengelola dan mentransformasi informasi dalam memori.

Beyer dalam Hassoubah (2011:3), menyatakan bahwa kemampuan berpikir kritis ini meliputi keterampilan untuk menentukan kredibilitas suatu sumber, membedakan antara yang relevan dan yang tidak relevan, membedakan fakta dari penilaian, mengidentifikasi dan mengevaluasi asumsi yang tidak terucapkan, mengidentifikasi bias yang ada, mengidentifikasi sudut pandang, mengevaluasi bukti yang ditawarkan.

\section{Kesimpulan dan saran}

\section{A. Kesimpulan}

Berdasarkan hasil penelitian dan pembahasan dari penelitian pengaruh penerapan model discovery learning melalui media nyata terhadap kemampuan konseptual dan berpikir kritis siswa pada pembelajaran IPA kelas 5 SD 45 kota Bengkulu adalah sebagai berikut:

1. Terdapat pengaruh yang signifikan dalam penerapan model discovery learning melalui media nyata terhadap kemampuan konseptual siswa pada materi pembelajaran IPA kelas 5 SD kota Bengkulu, sehingga model discovery learning melalui media nyata sangat layak digunakan dalam pembelajaran IPA untuk meningkatkan kemampuan konseptual siswa kelas V SD. Hal tersebut terlihat dari hasil uji pada pemahaman konsep bahwa nilai $t_{\text {hitung }}>t_{\text {tabel }}$ $(1,90>1,67)$. Nilai rata-rata pemahaman konsep kelas eksperimen adalah 80,53 dan kelas kontrol 77,43.

2. Terdapat pengaruh yang signifikan dalam penerapan model discovery learning melalui media nyata terhadap kemampuan berpikir kritis siswa pada materi pembelajaran IPA kelas 5 SD kota Bengkulu, sehingga model discovery learning melalui media nyata sangat layak digunakan dalam pembelajaran IPA untuk meningkatkan pemahaman berpikir kritis siswa kelas V SD. Hal tersebut terlihat dari hasil uji pada kemampuan berpikir kritis bahwa nilai $t_{\text {hitung }}$ $>t_{\text {tabel }}(1,86>1,67)$. Nilai rata-rata pemahaman konsep kelas eksperimen adalah 82,63 dan kelas kontrol 74,12.

\section{B. Saran}

Berdasarkan hasil penelitian dan kesimpulan dalam penelitian ini, maka dapat diajukan saran sebagai berikut:

1. Lakukan penelitian lanjutan pengaruh penerapan model discobery learnig melalui media nyata terhadap kemampuan pemahaman konsep pada materi yang lain.

2. Lakukan penelitian lanjutan pengaruh penerapan model discobery learnig melalui media nyata terhadap kemampuan berpikir kritis siswa pada materi yang lain 
3. Bagi peneliti lanjutan, teisis ini dapat dijadikan rujukan atau dikembangkan untuk penelitian selanjutnya mengenai penerapan model discovery learning melalui media nyata dalam meningkatkan pemahaman konseptual dan berpikir kritis siswa.

\section{DAFTAR PUSTAKA}

Anggareni. 2013. Impementasi Strategi Pembelajaran Inkuiri Terhadap Kemampuan Berpikir Kritis dan Pemahaman Konsep IPA Siswa SMP,Singaraja: Universitas Pendidikan Ganesha.

Arikunto. 2013. Dasar-dasar Evaluasi Pendidikan. Jakarta: Bumi Aksara.

Asrul. 2011. Penerapan Metode Penemuan Terbimbing dalam pembelajaran Matematika Untuk Meningkatkan Pemahaman Konsep dan Berpikir Kritis Siswa Sekolah Dasar. Sumedang: Kampus Sumedang.

Firosalia. 2016. Pengaruh Penerapan Model; Pembelajaran Discovery Learnin Terhadap Hasil Belajar IPS Siswa Kelas IV SD. Salatiga: Universitas Kristen Satya Wacana salatiga.

Fisher Alec. 2009. Berpikir Kritis. Jakarta: Penerbit Erlangga.

Hamzah. 2014. Evaluasi Pembelajaran Matematika. Jakarta: Raja Grafindo Persada.

Karwono. 2017. Belajar dan Pembelajaran. www.lampost.co/hastag-Metro.

Karwono. 2017. Pembelajaran sebagai perangkat kegiatan eksterna. https://karwono.wordpress.com/2011/02/22 /.
Kilpatrick dan Findell.2002. Mengemukakan indikator pemahaman Konsep. e-journal. stkipsiliwangi.ac.id/index.php.

Kurniasih. 2017 . Konsep dan Proses Pembelajaran. Jakarta: Kata Pena.

Lestari, K.E.\& Yudhanegara,M.R. 2017.Penelitian Pendidikan Matematika. Bandung: Refika Aditama.

Nasir. 2011. Penelitian eksperimen. https://indrienola.wordpress.com/

Ni Putu. 2015. Analisis Pemahaman Konsep Dalam Pelajaran Ipa Pada Siswa Kelas Iv Sd Di Gugus Ii Kecamatan Banjar. Bali: Universitas Pendidikan Ganesha Singaraja.

Parmin. 2009. Pengaruh Penggunaan Media Model Dan Gambar Terhadap Prestasi Belajar Ilmu Pengetahuan Alam Ditinjau Dari Motivasi Belajar Siswa.Surakerta: Universitas Sebelas Maret.

Purwanto. 2008. Pemahaman konsep. eprints.ums.ac.id/11594/13/.

Riduwan. 2013. Dasar-dasar Statistika. Bandung:Alfabeta.

Slavin. R.E. 2008. Cooperative Learning, Teori, Riset, dan Praktik. Bandung: Nusa Media.

Sugiyono. 2010. Metode Penelitian pendidikan. Bandung: Alfabeta.

Sugiyono. 2011. Alat Peraga dalam Pembelajarn Matematika (Makalah Disampaikan pada Pelatihan Materi Matematika KKG MI Kec. Trincing ,Secang, Jawa Te- ngah tanggal:20 Juli 2011).

Suherman. 2001. Beberapa keunggulan metode penemuan juga Diungkapkan. https://herdy07.wordpress.com/2010/05/.

Suryabrata. 2010. Tujuan Penelitian Eksperimen.

Repository.upi.edu/16166/5/S_JEP. 
Trianto. 2010. IPA. Rangkuman pustaka.blogspot.com.

Widyadnyana. 2014. Pengaruh Model Discovery Learning Terhadap Pemahaman Konsep IPA dan Sikap Ilmiah Siswa SMP.Tembuku: Universitas Pendidikan Ganesha.

Winarni. 2012. Inovasi Dalam Pembelajaran IPA. Bengkulu: FKIP UNIB. 